\title{
Implementasi Pola Komunikasi Antar Pribadi Pada Remaja
}

\author{
Djudjur Luciana Radjagukguk ${ }^{1}$ \\ ${ }^{1}$ Universitas Nasional Jakarta, dluciana_rajagukguk@yahoo.co.id
}

\begin{abstract}
ABSTRAK
Berkomunikasi secara terbuka dan luwes pada diri remaja dengan seseorang akan sangat terbantu dalam menyelesaikan persoalan-persoalan yang dialami. Komunikasi bagian terpenting dalam kehidupan, sebagai mahkluk sosial tentu saja semua manusia yang ada di muka dunia ini akan besosialisasi melalui komunikasi. Dengan komunikasi seseorang akan sangat terbantu dalam menyelesaikan persoalan-persoalannya. Banyak kasus, komunikasi lebih didominasi dalam bentuk verbal (kata-kata) dibanding dengan non verbal (simbolik). Beberapa penelitian di Amerika, menegaskan bahwa waktu manusia di luar waktu tidur 70\% digunakan untuk berkata-kata. Artinya, bilaseseorang mampu membangun kata-kata yang baik, orang itu telah menggunakan $70 \%$ waktunya untuk membangun sebuah kebaikan. Sebaliknya bila $70 \%$ itu digunakan untuk hal-hal yang jelek jelas orang itu sedang membuat kubangan bagi kegagalannya sendiri. Ketakutan dan kecemasan berkomunikasi menjadikan batu sandungan yang besar dalam diri seorang remaja. Sehingga, dapat menghilangkan kepercayaan diri. Kecemasan berkomunikasi amat mempengaruhi kredebilitas anak remaja. Pada kehidupan sehari-hari komunikasi antarpribadi merupakan suatu proses komunikasi (penyampaian pesan dari komunikator kepada komunikan) adalahhal yang paling efektif dapat dilakukan secara sederhana. Tujuan penelitian ingin mengetahui dan mengdeskripsikan implemtasikan pola komunikasi antarpribadi pada anak remaja. Metode yang digunakan melalui observasi dan wawancara mendalam kepada Ketua Karang Taruna dan Remaja RW 04 Kelurahan Sukmajaya Depok. Hal ini sangat diharapkan remaja memiliki kemampuan dalam berkomunikasi dalam menuangkan ide dan gagasannya, terlebih jika dilihat remaja adalah generasi penerus, sehingga mereka patut diberikan cara berkomunkasi antarpribadi secara baik. Hasil yang terlihat pada remaja Karang Taruna dan Remaja RW 04 Kelurahan Sukmajaya Depok para remaja mampu diajak untuk mengevaluasi diri dari setiap tindakan baik secara kelompok maupun individu.
\end{abstract}

Kata kunci :Implementasi, Pola Komunikasi Antarpribadi, Anak Remaja

ABSTRACT 
How to communicate openly and flexibly in adolescents will be very helpful in solving problems experienced. Communication is the most important part of life. as social beings, of course all humans in this world will socialize through communication. With communication, someone will be greatly helped in solving their problems. Many cases, communication is dominated in the form of verbal (words) compared to nonverbal (symbolic). Some studies in America, human activities are carried out by communication, $70 \%$ of the time is used to speak outside of bedtime. That is, if someone is able to build good words, that person has used $70 \%$ of his time to build a goodness. Conversely, if $70 \%$ is used for bad things, that person is making a puddle for his failure. Communication fear and anxiety make a big stumbling block in a teenager. So that, can eliminate selfconfidence. Communication anxiety greatly affects the credibility of teenagers. In everyday life, interpersonal communication is a communication process that is the delivery of messages from communicators to communicants, is the most effective and can be done simply. The purpose of this study is to find out and describe the implementation of patterns of interpersonal communication in adolescents. The method used, through observation and in-depth interviews to the head of Youth Karang RW 04 Sukmajaya Village Depok. This shows that adolescents are highly expected to have the ability to communicate and express their ideas and ideas, especially if it is viewed that adolescents are the next generation, so they should be given knowledge about how to communicate interpersonally well. The results seen in youth of Youth and Youth Youth RW 04 Sukmajaya Village Depok, teenagers are able to be invited to evaluate themselves from each action, both in groups and individuals.

Keywords: Implementation, Interpersonal Communication Patterns, Adolescents

\section{PENDAHULUAN}

Pola komunikasi merupakan bentuk hubungan antara dua orang atau lebih dalam proses pengiriman dan penerimaan pesan. Ada beberapa bentuk pola komunikasi dalam kehidupan manusia sehingga memudahkan untuk memilih pola yang mana cocok digunakan dalam kehidupannya untuk berkomunikasi dengan sesamanya.

Kenyataannya komunikasi juga bagian terpenting dalam kehidupan, sebagai mahkluk sosial tentu saja semua manusia yang ada di adadi belahan dunia akan besosialisasi melalui komunikasi. Kehidupan berkomunkiasi seseorang akan sangat terbantu dalam menyelesaikan persoalan-persoalan yang ada, tidak saja 
antara suami-istri, orangtua-anak (ayah-anak; ibu-anak), terlebih dalam diri anak remaja. Pada anak remaja sangat sulit berkomunikasi jika tidak tahu dimana letak komunikasi yang diinginkan remaja. Masa ini adalah masa yang rentan bagai anak remaja, untuk bisa mngungkapkan apa yangada di dalam hatinya.

Banyak kasus, komunikasi lebih didominasi dalam betuk verbal atau katakata. Beberapa penelitian di Amerika, mengutip M Fauzil Adhim, waktu manusia di luar waktu tidur 70\% digunakan untuk berkata-kata. Artinya bila dia mampu membangun kata-kata yang baik, dia telah menggunakan 70\% waktunya untuk membangun kebaikan. Sebaliknya bila 70\% itu digunakan untuk hal-hal yang jelek jelas dia sedang membuat kubangan untuk kegagalannya sendiri.

Ketakutan dan kecemasan berkomunikasi menjadikan batu sandungan yang besar bagi seorang seorang diri remaja, sehingga dapat menghilangkan kepercayaan diri. Kecemasan berkomunikasi amat mempengaruhi kredebilitas diri remaja. Gejala-gejala kecemasan dalam berbicara yang dijumpai seperti demam panggung, kecemasan berbicara, merasa tertekan, takut dinilai tidak sopan dan memiliki perasaan selalu takut berbicara dengan orang lain.

Pada kehidupan sehari-hari komunikasi antarpribadi merupakan suatu proses komunikasi yaitu penyampaian pesan dari komunikator kepada komunikan. Ini hal yang paling efektif dan dilakukan secara sederhana. Karena komunikasi antarparibadi berpusat pada kualitas komunikasi antarpartisipan bukan kwantitas. Mereka saling berhubungan satu sama lain merupakan pribadi yang unik, bisa memilih, mempunyai perasaan, dan bisa mengembangkan diri masing-masing dalam berkomunkasi.

Dalam berkomunkasi dapat menyalurkan dan meluapkan aspirasi hati yang terpendam. Salah satu dari kontroling diri, cermin, inspirasi, motivasi dan pembentukan image. Untuk itu komunikasi antarpribadi harus terjalin baik dan terbuka untuk pencapaian karakter dalam pertumbuhan menjadi orang sukses.

Anak remaja dapat dibagi dalam dua kategori, remaja awal yaitu berada pada rentang usia 13 sampai 17 tahun dan remaja akhir berada pada rentang usia 


\section{PERSESPSI}

17 sampai dengan 21 tahun. Pada usia ini remaja mencari jatidirinya dan mencoba untuk bergaul dan berkomunikasi dengan orang lain termasuk keluarganya, ibu dan ayah ataupun saudaranya.

Remaja mulai berfikir mengenai keinginan mereka sendiri, lalu mengenai ciri-ciri ideal bagi mereka sendiri dan orang lain. Artinya siapa yang pantas untuk mereka ajak bicara atau berkomunikasi dalam mengembangkan dirinya. Terkadang membandingkan diri mereka dengan orang lain dan berfikir tentang bagaimana memecahkan suatu masalah dan menguji pemecahan masalah secara sistematis.

Menurut Charlotte Buhler, pada masa pubertas atau masa remaja awal terdapat gejala yang disebut gejala "negative phase", berarti bahwa individu mengambil sikap “anti” terhadap kehidupan atau kehilangan sifat-sifat baik yang sebelumnya sudah berkembang. Gejala 'negative phase' yaitu keinginan untuk menyendiri, berkurang kemampuan untuk bekerja; kegelisahan, kepekaan perasaan, pertentangan sosial dan rasa kurang percaya diri (lack of self confidence).

Hal yang paling menonjol adalah rasa kurang percaya diri (lack of self confidence). Padahal rasa percaya diri merupakan hal yang sangat penting bagi pertumbuhan dan perkembangan individu, karena kepercayaan diri merupakan keyakinan dalam diri seseorang untuk dapat menanggapi segala sesuatu dengan baik sesuai dengan kemampuan dirinya yang dimiliki

Contoh ciri-ciri remaja yang mempunyai kepercayaan diri misalnya memiliki suatu sikap atau perasaan yakin atas kemampuan dirinya sendiri; bebas melakukan hal yang disukainya; mampu berinteraksi dengan orang lain; dan mempunyai dorongan berprestasi serta dapat mengenal kelebihan dan kekurangan diri sendiri.

Beberapa ciri remaja yang kurang percaya diri yaitu merasa dirinya kecil ketika tidak berdaya menghadapi tindakan orang lain, misalnya ketika kemampuan untuk berbicara kurang dipahami orang lain dalam menyampaikan 
pesan. Sehingga remaja, biasanya takut melakukan kesalahan dan juga takut ditertawakan orang lain merasa jadi tidak berharga dan tidak ada artinya.

Akhirnya, remaja cenderung sebisa mungkin menghindari situasi komunikasi, remaja cenderung takut pada orang lain yang akan mengejeknya atau menyalahkannya, yang menjadikan individu tersebut akan banyak menghadapi masalah; kemampuan berfikir remaja lebih dikuasai oleh emosional, sehingga kurang mampu menyesuaikan dengan pendapat orang lain, dan dalam komunikasi terjadi hubungan interpersonal.

Menurut Rahmat ada beberapa faktor-faktor yang menumbuhkan hubungan

interpersonal adalah : a) Percaya (trust); b) Sikap suportif. Sikap suportif adalah sikap dalam komunikasi seseorang apabila tidak menerima, tidak jujur, tidak empatis; c) Sikap terbuka (open mindedness). Dengan sikap percaya dan sikap suportif, sikap terbuka mendorong timbulnya saling pengertian, saling menghargai, dan yang paling penting yaitu saling mengembangkan kualitas hubungan interpersonal.

\section{KAJIAN LITERATUR}

Pola komunikasi adalah bentuk atau pola hubungan antara dua orang atau lebih dalam proses pengiriman dan penerimaan pesan. Sehinga dalam proses pengiriman dan penerimaan pesan bentuk perubahan dari perilaku sangat bervariasi, sesuai dengan konsep yang digunakan para ahli. Menurut WHO dalam Notoatmojo (2007), perubahan perilaku dikelompokanmenjaditiga:

a. Perubahan alamiah, Perilaku manusia selalu berubah, dimana sebagian perubahan disebabkan kejadian alamiah. Apabila dalam masyarakat sekitar terjadi suatu perubahan lingkungan fisik atau sosial budaya dan ekonomi, maka anggota masyarakat di dalamnya juga akan mengalami perubahan.

b. Perubahan terencana. Perubahan perilaku ini terjadi karena direncanakan sendiri olehsubyek.

c. Kesediaan untuk berubah. Apabila terjadi suatu inovasi atau program pembangunan di dalam masyarakat, maka yang sering terjadi adalah sebagian orang sangat cepat untuk menerima inovasi atau perubahan tersebut (berubah perilakunya, dan sebagian yang lain sangat lambatuntuk 


\section{PERSESPSI}

menerima inovasi dan perubahan tersebut. Hal ini disebabkan setiap orang mempunyai untuk berubah yang berbeda-beda meskipun kondisinyasama.

Dean Barnlund (1975) menjabarkan komunikasi antarpribadi sebagai "Perilaku orang-orang pada pertemuan tatap muka dalam situasi sosial informal dan melakukan interaksi terfokus lewat pertukaran isyarat verbal dan non verbal yang saling berbalasan.

Sedangkan menurut Gerald Miller, et.al (1982) membedakan antara komunikasi dan komunikasi yang bukan antarpribadi. Dalam komunikasi bukan antarpribadi, informasi yang diketahui para partisipan yang terlibat bersifat kultural atau sosiologis (keanggotaan kelompok). Sebaliknya, partisipan dalam komunikas melandaskan persepsi dan reaksi mereka pada karakteristik psikologi yang unik dari personal atau individu masing-masing.

John Steward dan Gary D’Angelo (1980) memandang komunkasi antarpribadi berpusat pada kualitas komunikasi yang terjalin dari masing-masing pribadi. Partisipan berhubungan satu sama lain sebagai seorang pribadi. Partisipan berhubungan satu sama lain sebagi seorang pribadi yang memiliki keunikan, mampu memilih, berperasaan, bermanfaat, dan merefleksikan dirinya sendiridaripada sebagai objek atau benda.

Komunikasi antarpribadi merupakan pertemuan dari paling sedikit dua orang yang bertujuan untuk memberikan pesan dan informasi secara langsung.

Joseph DeVito (1989) mengartikan komunikasi antarpribadi ini sebagai proses pengiriman dan penerimaan pesan-pesan antar dua orang atau sekelompok kecil orang dengan beberapa effect atau umpan balik seketika.

Menurut Muhammad Budyatna (1997;6) apabila prediksi mengenai hasil komunikasi terutama di dasarkan pada tingakat analisis kultural dan sosiologis, maka komunikator terlibat dalam komunikasi non-antarpribadi. Apabila prediksi terutama di dasarkan pada tingkat analisis psikologis, maka komunikator terlihat dalam komunikasi antarpribadi. 
Perubahan perilaku pada anak remaja dalam komunikasi antarpribadi merupakan proses pertukaran informasi yang dianggap penting dan menjadi keharusan bagi setiap anak, baik secara formasl atau informal. Tidak seorang pun anak remaja tidak melakukan komunikasi dalam hidupnya, karena setiap orang akan berusaha menjalin dan membuka komunikasi dengan orang lain.

Pada komunikasi antar pribadi ada beberapa tahap dalam berkomunikasi, menurut Edi Harapan (2014; 37-39), yaitu lima tahap dalam berkomunikasi John Powell (Staf CLC, 1985) membedakan komunikasi dalam lima tahap yaitu :

Tahap pertama atau tahap yang paling dangkal adalah basa basi. Ini biasanya terjadi antara dua orang yang bertemu secara kebetulan. Kedua, adalah membicarakan orang lain, yaitu pada tahap ini orang sudah mulai menanggapi, namun masih pada tahap dangkal khususnya belum mau berbicara tentang diri sendiri masing-masing.

Tahap ketiga adalah menyatakan gagasan dan pendapat. Pada tahap ini dua orang sudah mau saling membuka diri saling mengungkapkan perasaan. Namun, pengungkapkan diri tersebut masih terbatas pada tahap pikiran saja. Tahap keeempat adalah tahap mengemukakan isi hati atau perasaan. Ada yang mengatakan bahwa emosi atau perasaan adalah unsur yang membedakan orang yang satu dari lainnya.

Pada tahap terakhir, tahap kelima adalah hubungan puncak. Dimana tahap ini jalinan komunikasi ditandai dengan kejujuran, keterbukaan dan saling percaya mutlak diantara kedua belah pihak.

Pada penelitian ini, pola komunikasi antarpribadi yang dilakukan Karang Taruna RW 04, melakukan pola komunikasi pada ketiganya. Namun terjadi lebih besar pada pola komunikasi perubahan alamiah, dimana setiap anggota dari Karang Taruna yang melakukan kegiatan akan mengalami perubahan. Bukan hanya pada anggota Karang Tarunanya saja tetapi juga pada pemimpin organisasi saat melaksanakan tugasnya sebagai ketua. Pimpinan 
mempengaruhi berbagai kegiatan ddari setiap anggota organisasi melalui komunikasi interpersonal.

Menurut Buntur Setiawan (2004;39) Implematsi adalah perluasan aktifitas yang langsung menyesuaikan proses interkasi antara tujuan dan tindakan mencapai serta memerlukan jaringan pelaksana untuk birokrasi yang efektif.

Menurut KBBI, implementasi yaitu penerapan atau pelaksanaan. Dalam komunikasi antarpribadi diharapkan anak remaja dapat menerapkan atau melakukan proses komunikasi yang baik dan efektif dalam menyampaikan pesan.Menurut Singgih Gunarsa (1989;5) dari kepustakaan diadapatkan puberteit adalah masa antar 12 dan 16 tahun. Pengertian pubertas meliputi perubahanperubahan fisikdan psikis, seperti halnya pelepasan diri dari ikatan emosionil dengan orang tua dan pembentukan rencana hidup dan sistem nilai sendiri. Perubahan pada masa ini menjadi objek penyorotan terutama perubahan dalam lingkungan dekat, yakni dalam hubungan keluarga.

Adolecentia adalah masa sesudah pubertas, yakni amasa antara 17 dan 22 tahun. Pada masa ini lebih diutamakan perubahan dalam hubungan dengan lingkungan hidup yang lebih luas, yakni masyarakat di mana ia hidup.

Menurut Singgih $(1989 ; 24)$ akan selalu timbul pertanyaan mengapa tindakan remaja yang jelas merugikan tetap dijalankan remaja. Dari hasil penelitian berlandaskan berbagai cara pendekatan dan penagamatan dapat disimpulkan bahwa faktor-faktor yang mempengaruhi proses perkembangan seorang individu dapat dibagi dalam dua kelompok utama:

1. Faktor-faktor di dalam diri individu sendiri meliputi faktor-faktor endogen yang terdiri dari komponen hereditas (keturunan) dan faktor konsistusi.

2. Faktor-faktor berasal dari luar individu tercakup dalam faktor lingkungan: faktor eksogen: terdiri dari berbagai komponen lingkungan, lingkungan keluarga, lingkungan sosial, lingkungan geografis dan fasilitas-fasilitas yang ada dalam lingkungan seperti makanan dan kesempatan/perangsangan belajar. 


\section{METODE PENELITIAN}

Penelitian ilmiah pada dasarnya banyak bergantung pada cara peneliti mengumpulkan fakta.” (Jalaludin Rakhmat, 2006:23). Peneliti kualitatif adalah peneliti yang memiliki tingkat kritisme yang lebih dalam semua proses penelitian. Kekuatan kritisme peneliti menjadi senjata utama dalam menjalankan semua proses penelitian. Peneliti diarahkan oleh produk berpikir induktif untuk menemukan jawaban logis terhadap apa yang sedang menjadi pusat perhatian dalam penelitian, dan akhirnya produk berpikir induktif menjadi jawaban sementara terhadap apa yang dipertanyakan (Burhan Burgin,2006:5).

Sifat dari penelitian ini adalah deskriptif. Penelitian deskriptif yaitu penelitian yang berusaha untuk menuturkan pemecahan masalah yang ada sekarang berdasarkan data-data. Jadi penelitian deskriptif juga menyajikan data, menganalisis data dan mengintrepretasikan data (Cholid Norbuko,2005:44). Pendekatan deskripsi untuk memberi gambaran yang lebih jelas tenntang situasisituasi sosial. Pendekatan deskriptif lebih spesifik dengan memusatkan perhatian kepada aspek-aspek tertentu dan sering menunjukkan hubungan antara berbagai variabel (Nasution,2007:24).

Penelitian deskriptif hanya melukiskan keadaan obyek atau persoalannya. Selain itu tujuan dari penelitian deskriptif adalah untuk menggambarkan faktafakta dan realitas yang terdapat dilapangan mengenai implementasi pola komunikasi antarpribadi pada anak remaja. Subjek penelitian peneliti adalah Karang Taruna RW 04 sebagai tempat penelitian. Sedangkan obyek penelitian ini adalah implementasi pola komunikasi antarpribasi yang dianalisis pada anak remaja RW 04 di Kelurahan Mekarjaya KecamatanSukmajaya.

Tehnik pengumpulan data peneliti lakukan dengan teknik wawancara dan mempelajari data-data sekunder baik berupa dokumentasi mau pun data-data lain yang berkaitan dengan penelitian. Hal pertama adalah wawancara yaitu suatu bentuk komunikasi verbal semacam percakapan yang bertujuan untuk memperoleh informasi. 
Wawancara merupakan metode pengumpulan data yang digunakan untuk memperoleh informasi secara langsung dari sumbernya. Peneliti melakukan wawancara mendalam. Wawancara mendalamadalah "suatu cara mengumpulkan data atau informasi dengan cara langsung bertatap muka dengan informan agar mendapatkan data lengkap danmendalam".

Penulis memahami bahwa dalam jenis wawancara mendalam, wawancara yang dilakukan lebih bersifat informal, fleksibel, dan terbuka, sehingga memungkinkan adanya wawancara berulang pada narasumber yang sama dan dengan pertanyaan-pertanyaan yang lebih detail (Rachmat Kriyantono, 2010:102).

Key Informan (narasumber), tak hanya memberi keterangan tentang sesuatu kepada peneliti tetapi juga bisa memberi saran tentang sumber-sumber bukti lain yang mendukung serta menciptakan akses terhadap sumber yang bersangkutan (Yin, 2006:105).

Wawancara dilakukan untuk mengetahui implemantasi perubahan pola komunikasi antarpribadi pada anak remaja. Dari wawancara ini diharapkan juga diketahui berbagai latar belakang dibalik implementasi pola komunikasi antarpribadi.

\section{PEMBAHASAN}

Masa remaja merupakan masa labil bagi anak-anak yang sedang berkembang, dimana mereka ingin menunjukkan jati diri dalam kehidupan bermainnya. Namun, terkadang mereka lepas kontrol dari kehidupan yang normal ketika lingkungan mereka tidak menerima dengan senang hati. Disinilah, peran komunikasi dibutuhkan terutama lingkungan dalam rumah yaitu orangtua. Anak remaja dalam perkembangannya sangat membutuhkan tempat dalam mencurahklan segala perasaannya, sehingga mereka merasa nyaman dalam pergaulan. Tetapi semua itu dapat berjalan baik, ketika hubungan orangtua yaitu 
ayah-ibu, suami istri terjalin dengan baik, sehingga anak-anak mereka lebih terbuka dengan apa yang menjadi keinginnanya.

Remaja di RW 04 Kelurahan Mekarjaya Kecamatan Sukmajaya yang tergabung dalam Karang Taruna berjumlah 30 orang, tetapi yang aktif tidak lebih dari 10 -15 remaja. Hal ini, dikarenakan berbagai aktivitas yang padat karena masih sekolah. Iqbal Ferdinant, Ketua Karang Taruna RW 04 Kamboja menegaskan bahwa remaja yang terkabung dalam karang taruna ini sangat menjalin kerjasama dengan baik. Berbagai aktivitas juga mereka lakukan, dan biasanya akan banyak kesibukan menjelang bulanRahmadhan.

Saat bulan Rahmadhan, biasanya sore hari diadakan pengajian sambil menunggu magrib saatnya buka puasa, bahkan setiap seminggu sekali saat selesai Taraweh mereka akan mengadakan pertemuan terlebih membicarakan kegiatan-kegiatan apa saja yang akan dilakukan selama bulan puasa.

Begitu juga saat menjelang Hari Kemerdekaan Republik Indonesia setiap tanggal 17 Agustus setiap tahunnya, para Karang Taruna akan sibuk membentuk panitia untuk mengkoordinir setiap kegiataan yang diadaan di daerah tersebut. Berbagai aktivitas dilkaukan mulai dari pertandingan anak-anak, remaja bahkan sampai acara malam hiburan dalam pembagian hadiah.

Sehingga pertemuan yang sering diadakan Karang Taruna RW 04 harus dapat berkomunikasi dengan baik, komunkasi antarpribadi berpusat pada kualitas komunikasi yangterjalin dari masing-masing pribadi pada remaja. Partisipan berhubungan satu sama lain sebagai seorang pribadi. Partisipan berhubungan satu sama lain sebagi seorang pribadi yang memiliki keunikan, mampu memilih, berperasaan, bermanfaat, dan merefleksikan dirinya sendiri daripada sebagai objek atau benda.

Komunikasi antarpribadi merupakan pertemuan dari paling sedikit dua orang yang bertujuan untuk memberikan pesan dan informasi secara langsung, sehingga pola komunikasi yang dilakukan pada remaja karang Taruna RW 04 Sukmajaya terlihat: 


\section{A. Perubahan Alamiah, Perilaku Manusia Selalu Berubah, Sebagian Perubahan Disebabkan Kejadian Alamiah.}

Apabila dalam masyarakat sekitar terjadi suatu perubahan lingkungan fisik atau sosial budaya dan ekonomi, maka anggota masyarakat di dalamnya juga akan mengalami perubahan. Ini terlihat pada remaja RW 04 Kelurahan Mekarjaya Kecamatan Sukmajaya, dimana biasanya para remaja yang lebih banyak tertutup tapi ketika bertemu dengan teman-teman yang sebaya dengannya mengalami suatu perubahan terlebih ketika memilki satu hoby yang sama. Secara alamiah perubahan terjadi pada remaja RW 04, begitu yang dijelaskan Bapak Ngadi selaku Ketua RW 04 Kelurahan Mekarjaya Kecamatan Sukmajaya. Pertemuan yang diadakan sebulan sekali juga membuat para remaja dapat diskusi dengan mengeluarkan berbagai pendapat atau pun muncul ide-ide untuk membuat acara kebersamaan.

\section{Perubahan Terencana.}

Perubahan perilaku ini terjadi karena direncanakan sendiri olehsubyek. Tidak hanya itu ada memang beberapa remaja yang tetap tidak mau terlalu aktif, namun itu tidak menjadi masalah. Biasanya remaja tersebut memang lebih banyak diam di dalam rumah tetapi jika diikutsertakan dalam kepanitiaan misalnya 17 Agustus, para remaja itu akan aktif melakukan kegiatan.

\section{Kesediaan untuk berubah.}

Apabila terjadi suatu inovasi atau program pembangunan di dalam masyarakat, maka yang sering terjadi adalah sebagian orang sangat cepat untuk menerima inovasi atau perubahan tersebut. Perubahan perilaku pada remaja RW 04 memang ada yang cepat mampu melakukan dengan baik, namun ada juga perubahannya yang lambat.

Perubahan perilaku pada anak remaja dalam komunikasi antarpribadi merupakan proses pertukaran informasi yang dianggap penting dan menjadi keharusan bagi setiap anak, baik secara formasl atau informal. Tidak seorang 
pun anak remaja tidak melakukan komunikasi dalam hidupnya, karena setiap orang akan berusaha menjalin dan membuka komunikasi dengan orang lain.

Beberapa faktor-faktor yang mempengaruhi proses perkembangan seorang remaja yaitu terkadang memang datang daklam diri remaja itu sendiri, merejka tidak merasa percaya diri kalau mereka memiliki kemampuan yang sama dengan teman mereka, sehingga kadang-kadang mereka lebih tertutup tidak terbuka. Selain itu faktor, keluarga yang terkadang orangtua tidak mendukung mereka bersosialisasi, lebih menguitamakan mereka belajar.

Kesediaan untuk berubah. Apabila terjadi suatu inovasi atau program pembangunan di dalam masyarakat, maka yang sering terjadi adalah sebagian orang sangat cepat untuk menerima inovasi atau perubahan tersebut. Perubahan perilaku pada remaja RW 04 memang ada yang cepat mampu melakukan dengan baik, namun ada juga perubahannya yang lambat.

Perubahan perilaku pada anak remaja dalam komunikasi antarpribadi merupakan proses pertukaran informasi yang dianggap penting dan menjadi keharusan bagi setiap anak, baik secara formasl atau informal. Tidak seorang pun anak remaja yang tidak melakukan komunikasi dalam hidupnya, karena setiap orang akan berusaha menjalin dan membuka komunikasi dengan orang lain.

Sehingga jika remaja RW 04 mengadakan acara, yang mengikuti paling banyak 15 orang, meski anggota remaja ada 30-an. Tetapi hal itu tidak membuat Ketua karang Taruna RW 04 putus asa, dan tetap saja beberapa kegiatan para remaja itu dilibatkan.

\section{SIMPULAN}

Anak remaja dalam perkembangannya sangat membutuhkan tempat dalam mencurahklan segala perasaannya, sehingga mereka merasa nyaman dalam pergaulan. Tetapi semua itu dapat berjalan baik, ketika hubungan orangtua yaitu ayah-ibu, suami istri terjalin dengan baik, sehingga anak-anak mereka lebih 


\section{PERSERSI}

terbuka dengan apa yang menjadi keinginnanya.Tidak semua anak di RW 04 masuk dalam Karang Taruna, penyebabnya ada yang merasa malu, tidak percaya diri, bahkan tertutup tidak bersosialisasi. Selain itu Kurangnya bentuk kegiatan yang di lakukan, hanya pada saat bulan Rahmadan dan 17 Agustus-an, tidak acara rutinitas yang dilakukan setiap bulan. Karena itu ada kesulitan yang dialami oleh Ketua karang Taruna untuk mempertemukan setiap bulan anggotanya.

\section{REFERENSI}

Burgin, Burhan. (2007). Metode Penelitian Sosial. Surabaya: Airlangga UniversityPress.

Budtyana. Mona (1997). Teori Komunikasi Antarpribadi. Kencana Prenada Media Group.

Gunarsa, Singgih (1989). Psikologi Remaja. P.T. BPK Gunung Mulia. Anggota IKAPI

Harapan. Ahmad. (2014). Komunikasi Antarpribadi. Perilaku Insani Dalam Organisasi Pendidikan. PT. Rajagrafindo Persada. Depok

Kriyantono, Rachmat. (2010). Tehnik Praktis, Riset Komunikasi. Jakarta: Prenada Media Group.

Moleong, Lexy, J. (2007). Metodologi Penelitian Kualitatif, Edisi Revisi. Bandung: Remaja Rostakarya.

Norbuko, Cholid dan Abu Achmadi. (2005). Metodologi Penelitian, Jakarta:BumiAkasara

Soewajadi, Jusuf. (2003). Metodologi Penelitian Sosial. Jakarta: GrafikaIndah

S. Nasution. (2004). Research (Penelitian Ilmiah). Jakarta : PT. BumiAksara

Rakhmat, Jalaluddin.(2006). Metode Penelitian Komunikasi, Dilengkapi Contoh Statistik. Bandung: RemajaRosdakarya 
Van Eymeren, Margawati. (2014). Media Komunikasi Dan Dampaknya Terhadap Kebudayaan: Analisis Atas Pandangan Herbert Marshall McLuhan. Jakarta: Pusat Kajian Filsafat DanPancasila

Yin, Robert, K. (2006). Studi Kasus Desain dan Metode. Jakarta: PT. Raja Grafindo Persada. Yunus, Syarifudin. (2010). Jurnalistik Terapan. Bogor: GhaliaIndonesia

\section{BIODATA PENULIS}

Dosen tetap di Prodi Ilmu Komunikasi FISIP, Universitas Nasional, Jakarta. Saat ini menjabat sebagai Kepala Laboratorium Unas Radio. 